\title{
Management of autoimmune hemolytic anemia in children and adolescents: A single center experience
}

\author{
Çocuk ve ergenlerde otoimmün hemolitik anemi tedavisi: Tek merkez \\ deneyimi
}

\author{
Nazan Sarper, Suar Çakı Kılıç, Emine Zengin, Sema Aylan Gelen \\ Department of Pediatric Hematology, Faculty of Medicine, Kocaeli University, Kocaeli, Turkey
}

\begin{abstract}
Objective: To present and discuss the treatment of autoimmune hemolytic anemia (AIHA).

Materials and Methods: The medical records of all patients $(n=19)$ diagnosed in a tertiary hematology center between 1999 and 2010 were retrospectively reviewed.

Results: Median age at diagnosis of AIHA was 5 years (range: 4 months-17 years). In all, 13 patients had primary (idiopathic) AIHA, whereas 2 had primary Evans Syndrome (ES), 2 had autoimmune lymphoproliferative syndrome (ALPS)+ES, and 1 had Wiskott-Aldrich syndrome (WAS) +AIHA. Among the 13 primary idiopathic AIHA patients, 9 recovered following a 4-8-week course of prednisolone treatment without relapses, whereas 3 patients required a longer course of prednisolone. One AIHA patient that was very resistant to prednisolone recovered after cyclosporine $A$ was added to the treatment. All patients with primary idiopathic AIHA were in remission for a median of 3 years (range: 4 months-10 years) at the time this manuscript was written. Among the patients with primary ES, 2 had relapses similar to the ALPS patients. Splenectomy was performed in 1 primary ES patient, who at the time this report was written was also in remission. One ALPS patient required the addition of mycophenolate mofetil due to prednisolone resistance. The WAS patient was treatment resistant and died due to septicemia.

Conclusions: Primary AIHA in pediatric patients generally has an acute onset and good response to corticosteroids. Primary or secondary ES has a chronic or relapsing course, and treatment may require other immunosuppressive agents in addition to corticosteroids. Complications of splenectomy must not be underestimated in patients with underlying immunodeficiency. AlHA often causes considerable morbidity and mortality in WAS. (Turk J Hematol 2011; 28: 198-205)
\end{abstract}

Key words: Autoimmune hemolytic anemia, Evans Syndrome, childhood, autoimmune lymphoproliferative syndrome

Received: September 23, $2010 \quad$ Accepted: March 05, 2011

\section{Özet}

Amaç: Bu makalede otoịmmün hemolitik anemi tedavisinin tartışılması amaçlanmıştır.

Yöntemler ve Gereçler: Üçüncü basamak bir hematoloji merkezinde 10 yıl içinde tanı alan tüm otoim- 
mün hemolitik anemi olgularının (OİHA) $(n=19)$ hastane kayıtları geriye dönük olarak incelenmiștir. Tanı sırasında ortanca yas 5 (4 ay-17 yaş) tir. On üç hastada primer (idyopatik) OIHA, 3 hastada primer Evans Sendromu (ES), 2 hastada otoimmün lenfoproliferatif sendrom (OLPS) +ES, ve 1 hastada Wiskott-Aldrich sendromu (WAS) +OIHA saptanmıştır. On üç primer OİHA'li hastadan dokuzu 4-8 haftalık prednizolon tedavisine cevap verirken ve nüks etmezken, üç hasta daha uzun süreli prednizolon gerektirdi. Hastalardan biri prednizolona oldukça dirençliydi ve siklosporin A (CsA) ilavesiyle hemoliz kontrol altına alınabildi. Tüm primer OIHA'li hastalar ortalama 3 yıllık (4 ay-10 yıl) takipte remisyondaydı. Primer ES'lu hastaların ikisinde OIHHA, OLPS'li hastalara benzer şekilde nükslerle seyretti. Primer ES'li hastaların birine splenektomi yapıldı ve halen remisyondadır. OLPS'li hastaların biri prednizolona ilave olarak dirençli OIHHA nedeniyle mikofenolat mofetil de gerektirdi. WAS lı hasta dirençli OİHA atağı sırasında septisemi ile kaybedildi.

Sonuç: Çocukluk çağında primer OIHA genellikle kortikosteroide iyi cevap veren akut bir seyir gösterirken, primer veya sekonder ES nükslerle giden kronik bir seyir gösterir ve tedavide kortikosteroidlere ilave olarak diğer immunosupresif ajanlar da gerekebilir. Altta yatan immün yetersizlik olduğunda splenektominin komplikasyonları göz ardı edilmemelidir. WAS'da OİHA kayda değer morbidite ve mortalite nedenidir. (Turk J Hematol 2011; 28: 198-205)

Anahtar kelimeler: Otoimmün hemolitik anemi, Evans sendromu, çocukluk çağı, otoimmün lenfoproliferatif sendrom

\section{Introduction}

Autoimmune hemolytic anemia (AIHA) is characterized by the production of antibodies directed against red blood cells (RBCs). These antigens initiate RBC destruction via the complement and reticuloendothelial systems [1]. AIHA follows viral infection or vaccination more often in children than in adults [2]. Immunodeficiency or malignancy (especially malignancies of lymphoreticular tissues), systemic lupus erythematosus (SLE), and other types of collagen vascular diseases are the most common causes of secondary AIHA in children [3]. Also some rare disorders such as giant cell hepatitis may cause AIHA [4].

Childhood AIHA often presents as an acute selflimited illness, with good response to short-term steroid therapy in $80 \%$ of the patients [5]. In infants and adolescents onset can be insidious, with a tendency to become chronic [6]. When there is underlying immune deficiency control of the hemolytic process is not always easy, and the addition of immunosuppressive drugs and splenectomy further increase the risk of severe infections and mortality. Although corticosteroids are always the first-line therapy, there are many alternative second and third line treatments. AIHA is an uncommon condition; treatment responses are not standard and there is a lack of prospective controlled trials for determining the optimal therapy. Hematologists must individually tailor therapy for every chronic or unresponsive patient. Herein we present our experience with 19 pediatric and adolescent patients with
AIHA and Evans syndrome (ES), and a discussion of treatment options in the light of the literature is reviewed.

\section{Materials and Methods}

The medical records from a single tertiary pediatric hematology center that was established in 1999 were retrospectively reviewed. All patients with AIHA and ES that were diagnosed and/or followed-up between 1999 and 2010 were included in the study. The study protocol was approved by the Kocaeli University Ethics Committee. Diagnoses were based on low-level hemoglobin, fragmented red cells, microspherocytes, polychromasia, macrocytosis, nucleated red cells on peripheral blood smear, elevated reticulocytes, and positive direct Coombs test (IgG+C3). Age, gender, underlying disease associated with AIHA, complete blood counts, reticulocyte counts, Coombs test results, treatment drugs, splenectomy, treatment responses, relapses, and follow-up periods were recorded. ES was defined as the combination of (either simultaneously or sequentially) autoimmune hemolytic anemia, immune thrombocytopenic purpura (ITP) and immune neutropenia. AIHA and ES were defined as the primary disease when there was no underlying disease, such as autoimmune lymphoproliferative syndrome (ALPS), congenital immunodeficiency, common variable immunodeficiency, SLE, and lymphomas.

Patients were treated with oral prednisolone 2-4 $\mathrm{mg} / \mathrm{kg} /$ day in 2-3 divided doses for 2-4 weeks, with tapering over another 2-6 weeks. If hematological 
response was not good, prednisolone $30 \mathrm{mg} / \mathrm{kg} /$ day was administered intravenously for 3 days. If the $\mathrm{Hb}$ level decreased during steroid tapering, the dose reverted to the preceding dose. Patients were also transfused with packed red cells if their $\mathrm{Hb}$ was $<7 \mathrm{~g} / \mathrm{dL}$. Patients were defined as steroid responsive if the $\mathrm{Hb}$ level was stable or increased along with decreased reticulocyte count within $14 \mathrm{~d}$ of starting steroid treatment.

Relapse was defined as a decrease in $\mathrm{Hb}$ while tapering steroid treatment or following discontinuation of corticosteroids. Chronic AIHA was defined as symptoms and laboratory abnormalities persisting for $>6$ months. In unresponsive, steroid-dependent, and relapsing patients cyclosporine A (CsA) and, rarely, intravenous immunoglobulin (IVIG $1 \mathrm{~g} / \mathrm{kg} /$ day for $2 \mathrm{~d}$ ) or rituximab $375 \mathrm{mg} / \mathrm{m}^{2}$ weekly were tried as second-line treatment. In patients with primary or secondary ES corticosteroids and CsA were always administered, but mycophenolate mofetil (MM) 600 $\mathrm{mg} / \mathrm{m}^{2}$ b.i.d and azathioprine $3 \mathrm{mg} / \mathrm{kg} /$ day was also used as second-line treatments. Splenectomy was performed in chronic AIHA and ES patients if there was no evidence of underlying immunodeficiency. In patients with chronic AIHA, ES, or lymphoproliferation, history of frequent infections, growth failure, and eczema or any other autoimmune disease serum immunoglobulin assay and flow cytometric analysis of peripheral lymphocyte subsets and double negative T cells (DNTC) were also performed.

\section{Statistical methods}

SSPS v.13.0 for Windows and descriptive statistics were used to calculate median hemoglobin level, age, and follow-up period.

\section{Results}

Between 1999 and 2010 we followed-up 19 AIHA and ES patients (14 male and 5 female). In all, 17 of the patients had warm autoantibodies and 2 patients had negative Coombs test results. Patient characteristics, management, and outcome are presented in the Table 1. Median age at diagnosis of AIHA was 5 years (range: 4 months-17 years). In total, 7 (36.8 \%) of the patients were $<12$ months of age when AIHA was diagnosed; 13 patients (patients 1-13) had primary (idiopathic) AIHA, whereas 3 had primary ES, 2 had ALPS+ES, and 1 had Wiskott-Aldrich syndrome (WAS)+AIHA. Patients with ES had either sequential or simultaneous ITP. Median Hb concen- tration at admission was $5.6 \mathrm{~g} / \mathrm{dL}$ (range: $2.9-11.3 \mathrm{~g} /$ $\mathrm{dL}$ ). Patient 7 was followed-up for neutropenia for 3 months, followed by spontaneous recovery and the development of AIHA. Among the 5 patients with ES, 3 also had neutropenia. All neutropenia and thrombocytopenia responded to immunosuppressive therapy at the same time anemia did. All the patients, except patients 6,7 , and 13 , received packed red cells in addition to prednisolone at admission. Intravenous prednisolone was administered to infants during initial therapy due to ingestion problems. Generally, there was incompatibility during cross-matching. The least reactive packed red cells were transfused, and no severe hemolytic reactions attributable to transfusion were observed; however, patient 2 was previously typed as $\mathrm{AB} R \mathrm{Rh}$ positive at another center and the patient was transfused twice with $\mathrm{AB}$ Rh-positive packed red cells. Transfusion increased hemolysis. The patient's actual blood type was not known prior to admission. Transfusion with $\mathrm{O}$ Rh-negative packed red cells did not cause any hemolytic reaction and the patient was correctly typed as O Rh positive.

In all, 9 of the 13 primary idiopathic AIHA patients recovered following a 4-8-week course of prednisolone $2-4 \mathrm{mg} / \mathrm{kg} / \mathrm{day}$ without relapses, whereas 3 patients required a longer course of prednisolone treatment (patients 2, 6, and 8 due to relapse during prednisolone tapering). Patient 2 received low-dose prednisolone $(0.5 \mathrm{mg} / \mathrm{kg} /$ day $)$ for 20 months to control hemolysis. In total, 12 patients exhibited rapid response to prednisolone, but patient 12 was very resistant to prednisolone and responded after CsA was added to the treatment (started at a dose of 6 $\mathrm{mg} / \mathrm{kg} /$ day, with a target blood level of $200 \mathrm{ng} / \mathrm{mL}$ with monitoring). Patient 12 was also treated with IVIG $1 \mathrm{mg} / \mathrm{kg} /$ day for $2 \mathrm{~d}$, and rituximab $375 \mathrm{mg} \mathrm{m}-2$ QWK (only 2 doses were available due to off-label administration) was administered in an effort to discontinue CsA, but CsA dependence persisted for 13 months, after which time it was discontinued. All primary idiopathic AIHA patients were in remission for a median of 3 years (range: 4 months-10 years) at the time this report was written.

Among the patients with primary ES, 3 had relapses or chronic cytopenias. Relapses in patients 14 and 16 were controlled with 4-6-week courses of prednisolone, whereas patient 15 required CsA due to dependence on corticosteroids. Patient 14 had 3 AIHA attacks in 3 years, including AIHA-associated thrombocytopenia during the last attack. Patient 15 
Table 1. Characteristics, management, and outcome in the patients with AIHA and ES

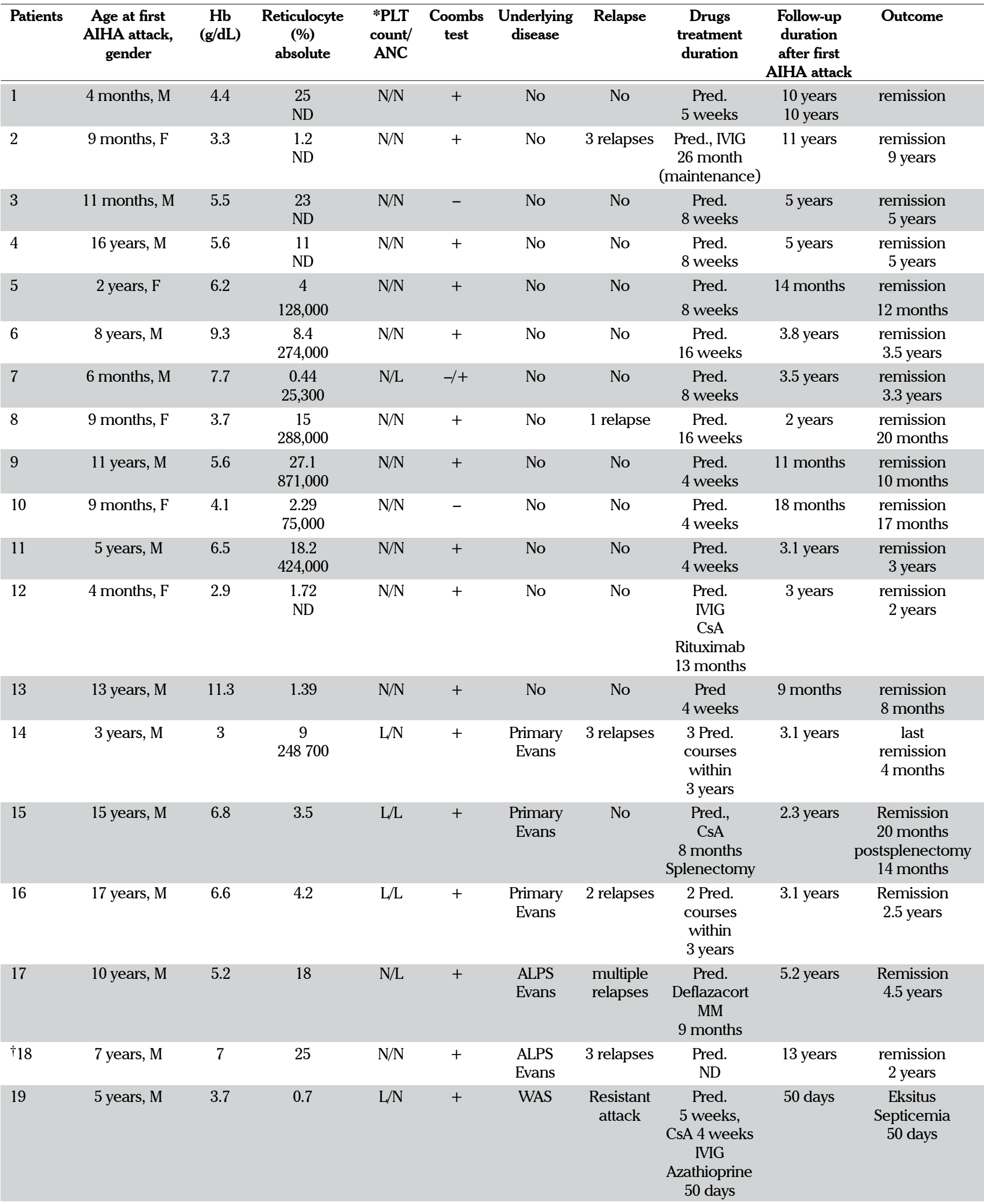

ANC: Absolute neutrophil count; PLT: platelets; N: normal; L: low

*Normal values: PLT: 150,000-450,000 mm³ ANC: $>1000 \mathrm{~mm}^{3}$ for infants and $>1500 \mathrm{~mm}^{3}$ for children $>1$ year of age

Coombs test=direct anti-globulin test; CsA: cyclosporin A; MM: mycophenolate mofetil; $\uparrow$ : followed-up elsewhere in the past; IVIG: intravenous immunoglobulin; ND: not defined 
presented with ITP at the age of 3 years and was previously treated with several courses of IVIG at other centers. On his admission to our center he had a history of chronic ITP and neutropenia. He had perianal and oral lesions (3-4 attacks yearly). We administered a 10-d course of antibiotics for each attack. Immunoglobulin levels were within normal levels during follow-up in our center. He did not have other infections indicative of immunodeficiency. When he was fifteen, he had an AIHA attack. The following year AIHA, thrombocytopenia, and neutropenia were in remission following CsA treatment and he underwent splenectomy; 14 months post-splenectomy he no longer had cytopenias or oral/ perianal infections. Patient 16 presented as chronic ITP with remissions and relapses, and responded to short-course prednisolone. When he was 17 years old he suffered 2 moderate attacks of AIHA that responded to short-course prednisolone. He had eczema, and low-level IgA and IgM, but no history of recurrent infections. At the time this report was written he was 20 years old and in remission. In his family history, there was a sister with ITP.

Patient 17 had ALPS (severe eczema, asthma, splenomegaly, lymphadenopathy, DNTCS 7\%)+ES and multiple relapses within a 9-month period: the patient presented with a very resistant, but finally prednisolone-dependent disease course. During maintenance treatment prednisolone was replaced by deflazacort to minimize adverse effects. Considering that $6 \mathrm{mg}$ of deflazacort has approximately the same anti-inflammatory potency as $5 \mathrm{mg}$ of prednisolone or prednisone, the patient received deflazacort $0.25 \mathrm{mg} / \mathrm{kg} /$ day during maintenance. MM $600 \mathrm{mg} / \mathrm{m}^{2}$ b.i.d was also added to the treatment. The patient's parents did not consent to offlabel use of rituximab. We recommended maintenance with $\mathrm{MM}$ to this patient after recovery of cytopenias, but his compliance with treatment was poor. This patient's autoimmune cytopenias were in remission for 4.5 years at the time this report was written. Patient 18 had ALPS (DNTS 6.3\%)+ ES and was previously diagnosed and followed-up at a different hematology center. The patient had 3 relapses in a 13 year-period, which were managed with prednisolone; as of the time this report was written he was in remission. He had low-level IgA and IgM. Patient 19, who was followed-up for WAS (congenital thrombocytopenia with small platelets, eczema, frequent infections, and absence of WAS protein), developed AIHA at the age of 5 years. Treatment began with prednisolone $4 \mathrm{mg} / \mathrm{kg}$ and increased to 9 $\mathrm{mg} / \mathrm{kg}$ on the second day due to severe hemolysis. On the $4^{\text {th }}$ day of treatment CsA $6 \mathrm{mg} / \mathrm{kg} /$ day was also administered to control hemolysis and prednisolone was decreased to $4 \mathrm{mg} / \mathrm{kg} / \mathrm{day}$. To control hemolysis, on day 9 azothiopurin $3 \mathrm{mg} / \mathrm{kg} /$ day was also administered but withdrawn on day 12 because it was ineffective. The patient's hemoglobin was stable on day 15 with prednisolon and CsA. Prednisolon was decreased to $3 \mathrm{mg} / \mathrm{kg} /$ day on day 20 but on day 27 hemoglobin began to decrease although the patient was on prednisolon and CsA. The patient required 15 packed red cell transfusions; he died due to septicemia on day 50 even though antimicrobial agents were administered for $12 \mathrm{~d}$.

\section{Discussion}

The clinical pattern of childhood AIHA in 70\%$80 \%$ of cases is predominantly acute transient-type lasting 3-6 months, which is similar to that observed in 11 of the 13 patients (84\%) in the present study with primary idiopathic AIHA that responded to a prednisolone course of only 4-8 weeks. As previously reported, the presented patients generally showed some improvement within 1 week of treatment onset [1].

The direct Coombs test (warm antibodies) was initially negative in 3 of the presented patients, but was subsequently positive in 1; all had a good response to prednisolone. Direct Coombs test results were reported as false negative in $2 \%-4 \%$ of cases [7]; this may be due to a low level of antibodies on red blood cells or low sensitivity of the test [8].

Some of the presented patients had reticulocytopenia. The cause of reticulocytopenia in AIHA is not well known. Reticulocytopenia might be indicative of concomitant accelerated immune-mediated destruction or autoantibody-induced apoptosis of $\mathrm{RBC}$ precursors in the bone marrow, temporary suppression of bone marrow activity secondary to infection, and/or delayed bone marrow response to hemolytic events $[9,10]$.

Transfusion can be difficult in AIHA patients due to difficulty in finding serocompatible blood. Pan agglutinating warm autoantibodies complicate cross-matching. A panreactive autoantibody can mask an existing alloantibody by making all donor units appear cross-match incompatible. It is best to use blood of the same $\mathrm{ABO}$ and Rh group with the least incompatibility [11]. Packed red cells should 
be transfused very slowly while the child is monitored for signs of hemolytic reactions [12]. In the present study 16 patients presented with acute hemolysis that could not be hemodynamically compensated and we had to perform transfusions. Following the above principals we did not observe transfusion-related hemolysis, except in patient 2 , in whom blood typing was troublesome due to AIHA.

Some steroid-dependent patients, such as patient 2 , may require maintenance with low-dose corticosteroids for an extended period [13]. In patients dependent on high daily doses (prednisolone $>0.5 \mathrm{mg} / \mathrm{kg}$ ) or in corticosteroid-refractory patients, cyclosporine should be tried before rituximab, cyclophosphamide, or splenectomy [5]. In the present study 1 patient with primary AIHA and 1 with primary ES required CsA. Two doses of rituximab were also administered to the AIHA patient, but its efficacy could not be determined because other drugs were also used. Rao et al. reported that 4 of 5 pediatric patients with AIHA had complete response (no response in 1 patient) after 4 doses and 1 patient had partial response after 6 doses of rituximab during 18 months of follow-up [14].

One study reported an $83 \%$ overall response rate to mercaptopurine in children with refractory cytopenias [15]. No other immunosuppressive agents were required in the presented patients with primary AIHA.

Some researchers emphasized the exclusion of an underlying disease for the definition of true ES [16], whereas others defined secondary ES based on underlying disease; we agree with the latter definition. ES is more than a coincidental combination of immune cytopenias; rather, it is a chronic state of profound dysregulation of the immune system [17]. Despite discrepancies in descriptions, all researchers conclude that cytopenias are recurrent, often refractory to IVIG, corticosteroids, and splenectomy, and that the syndrome may be fatal [18]. In very severe and refractory cases hematopoietic stem cell transplantation (HSCT) offers long-term cure, but again carries the risk of severe morbidity and transplant-related mortality [16]. The present study included 3 patients with primary ES, all of whom had a chronic course. There is consensus concerning the first- and second-line therapies in ES, but the timing of splenectomy must be considered individually, so that the morbidity and mortality associated with the procedure can be justified. In patient 15 we planned splenectomy to prevent sub- sequent attacks of AIHA and neutropenia-induced perianal infections, and to avoid the adverse effects of corticosteroids and CsA, and absence from school. Prior to his diagnosis of AIHA, despite thrombocytopenia he did not have any bleeding and perianal infections rarely had a negative affect on his quality of life. In contrast to our observation, some researchers reported that the role of splenectomy has never been established in ES and remissions last only 1-2 months without support [16,18$20]$. In a survey of ES mainly from the US and Canada 15 patients underwent splenectomy at a median age of 10 years (range: $1.2-26.5$ years). The duration of response was 1 week- 5 years, but median response was only 1 month [20].

Northon et al. evaluated the response to rituximab in 8 pediatric patients (aged 0.3-16 years) with ES from the literature [16]. Seven had complete remission during a follow-up period of 12-15 months, but 2 had relapses and achieved a second complete remission with rituximab. Although we did not try rituximab in our ES patients, the results seem encouraging and it may be worth trying before splenectomy [16]. Bader-Meunier et al. also reported successful results using rituximab therapy in ES. Complete or partial remission of at least one cytopenia was achieved in 13 of 17 patients (76\%), and persisted in 11 with a mean follow-up of 2.4 years (range: 0.5-7 years). Corticosteroid therapy was either stopped or tapered at $50 \%-100 \%$ of the baseline dosage in all long-term responders. Moderate side effects and infection occurred only in 4 patients and 1 patient, respectively. They suggested that rituximab should be promptly proposed as secondline treatment early in the course of pediatric ES refractory to steroids [21].

As in the presented patients, cytopenias may be sequential in ES. A second cytopenia may emerge over the course of 10 years [17]. Patient 14 presented with AIHA and also had ITP 3 years later. Patients 15 and 16 had chronic ITP, followed by AIHA 12 and 11 years later, respectively. In secondary ES underlying conditions may increase the risk of post-splenectomy sepsis and death. This procedure must be the last alternative after immunosuppressive treatments and rituximab have been tried. We did not perform splenectomy in patients with ALPS. Even in patients with primary ES some abnormalities in immunological studies have been reported. These abnormalities are hypogammaglobulinemia, decreased T-cell numbers, and an elevated IgG level [22,23]. Patient 16 
with primary ES had low IgA and IgM levels, but no history of recurrent infections.

AIHA and ITP have been observed in $23 \%-51 \%$ of ALPS patients in different series, and autoimmune neutropenia was also common (19\%-27\%). Autoimmune cytopenias may mark the clinical onset of the disease, even in the absence of signs of lymphoproliferation [24]. In patients diagnosed with ES laboratory work-up for ALPS is recommended. Markedly elevated DNTC ( $\geq 5 \%$ ) was a strong predictor of ALPS, whereas no patients with DNTC $<2.5 \%$ had ALPS, based on apoptosis testing [25]. In the present series DNTC in the patients with ALPS was $7 \%$ and $6.3 \%$. Autoimmune cytopenias in ALPS patients are often severe and refractory to treatment. As such, splenectomy has frequently been used in the management of ALPS; however, this approach is associated with significant risk of sepsis. Successful results have been reported with MM and sirolimus. Use of rituximab, with the intent to ablate autoreactive B cells, has been associated with neutropenia and persistent hypogammaglobulinemia [23]. Cytopenias in ALPS patients do not respond to IVIG [26]. In 1 of the presented ALPS patients we used only prednisolone, but in ALPS patient 17 we used MM in addition to corticosteroids. In patient 17 AIHA was severe and persisted for 9 months.

In a recent review by Teachey et al. an algorithm for the treatment of ALPS was proposed. Prednisolone must be the first-line therapy in moderate disease cases and MM must be the secondline treatment if there is intolerance or refractoriness to prednisolone. In severe cases of disease, sirolimus may be added to prednisolone as first-line therapy. In patients with inadequate response, refractory disease, or relapses, other agents, such as vincristine and methotrexate, are recommended as third-line treatment. Rituximab and splenectomy are considered fourth-line therapies [26].

In WAS the risk of developing an autoimmune disorder increases with age. Forty percent of males that survive the early complications of WAS develop one or more autoimmune conditions [27]. AIHA always develops before the age of 5 years [28]. It was reported that 2 WAS patients had resolution of AIHA after rituximab therapy, but 1 relapsed in 7 weeks and the other underwent HSCT and was lost to follow-up [29]. When long-term survivors of HSCT were evaluated $88 \%$ of HLA-identical and 38\% of HLA-non-identical HSCT receivers exhibited nor- mal autoimmunity [30]. The only curative therapy for WAS is early HSCT, even from alternative donors, before development of autoimmune complications and severe infections [31]. Although transplants from HLA-matched sibling donors have the best outcomes ( $81 \%-88 \%$ event-free survival), a matched unrelated donor also should be considered (71\% event-free survival); results are best in patients $<5$ years [32]. Chronic GVHD-independent autoimmunity is observed in $20 \%$ of patients and is strongly associated with mixed/split chimerism status, suggesting that residual host lymphocytes can mediate an autoimmune disease despite the coexistence of donor lymphocytes. Infectious complications related to splenectomy are also significant and splenectomy is not recommended prior to HSCT [30]. Other researchers also do not recommend splenectomy, which was commonly performed in the past to increase platelet counts and reduce the risk of fatal hemorrhage [33]. For patients that cannot undergo HSCT short-term immunosuppression with steroids, and/or CsA and IVIG remain treatment of choise for control of autoimmune cytopenias with carefull prophylaxis of infections.

Autoimmune complications are a cause of considerable morbidity and mortality in WAS patients [34]. Cyclophosphamide and azathioprine was effective in some patients with AIHA, although all these patients underwent HSCT. AIHA has never been cured by immunosuppressive therapy. These treatments are partially or transiently effective. HSCT is recommended as early as possible for patients with severe autoimmune complications [28]. A patient in the present study did not have a matched donor and died due to septicemia and resistant AIHA following immunosuppressive therapy.

In conclusion, childhood primary AIHA generally has an acute onset that is responsive to 4-8 weeks of corticosteroid therapy. In patients with primary ES, the clinical course is chronic. Similarly, secondary ES in ALPS also has a chronic and relapsing course. Treatment may require immunosuppressive treatment other than corticosteroids. Complications of splenectomy should not be underestimated in patients with underlying immunodeficiency. AIHA is associated with a high mortality rate in WAS patients and HSCT is recommended before the development of autoimmune cytopenias. Treatment of childhood AIHA must be individually tailored to patients and evidence of underlying disease must not be overlooked. 


\section{Conflict of interest statement}

The authors of this paper have no conflicts of interest, including specific financial interests, relationships, and/or affiliations relevant to the subject matter or materials included.

\section{References}

1. Gehrs BC and Friedberg RC. Autoimmune Hemolytic Anemia. Am J Hematol 2002;69:258-71.

2. Seltsam A, Shukry-Schulz S, Salama A. Vaccinationassociated immune hemolytic anemia in two children. Transfusion 2000;40:907-9:

3. Vaglio S, Arista MC, Perrone MP et al. Autoimmune hemolytic anemia in childhood: serologic features in 100 cases. Transfusion 2007;47:50-4.

4. Unal S, Kuskonmaz B, Balamtekin N et al. Autoimmune hemolytic anemia and giant cell hepatitis: Report of three infants. Turk J Hematol 2010;27:308-13.

5. Naithani R, Agrawal N, Mahapatra M, et al. Autoimmune hemolytic anemia in children. Pediatr Hematol Oncol 2007;24:309-15.

6. Gurgey A, Yenicesu I, Kanra T, et al. Autoimmune hemolytic anemia with warm antibodies in children: retrospective analysis of 51 cases. Turk J Pediatr 1999;74:245-57.

7. Agarwal B. Autoimmune hemolytic anemia. Indian J Pediatr 1998;65: 663-8.

8. Collins PW, Newland AC. Treatment modalities of autoimmune blood disorder. Semin Hematol 1992;29:64-74.

9. Liesveld JL, Rowe JM, Lichtman MA. Variability of the erythropoietic response in autoimmune hemolytic anemia: analysis of 109 cases. Blood 1987;69:820-6.

10. Van De Loosdrecht AA, Hendriks DW, Blom NR, et al. Excessive apoptosis of bone marrow erythroblasts in a patient with autoimmune haemolytic anaemia with reticulocytopenia. Br J Haematol 2000;108: 313-5.

11. Shah A. Acquired hemolyic anemia. Indian J Med Sci 2004;58:533-6.

12. Park DC, Yang CH, Kim KY. Autoimmune hemolytic anemia in children. Yonsei Med J 1987;28:313-21.

13. Murphy S, LoBuglio AF. Drug therapy of autoimmune hemolytic anemia. Semin Hematol 1976; 13:323-34.

14. Rao A, Kelly M, Musselman M, Ramadas J, Wilson D, Grossman W, Shenoy S. Safety, efficacy, and immune reconstitution after rituximab therapy in pediatric patients with chronic or refractory hematologic autoimmune cytopenias. Pediatr Blood Cancer 2008;50:822-85.

15. Sobota A, Neufeld EJ, Lapsia S, Bennett CM. Response to mercaptopurine for refractory autoimmune cytopenias in children. Pediatr Blood Cancer 2009;52:80-4.

16. Norton A, Roberts I. Management of Evans syndrome. Br J Hematol 2005;132:125-37.

17. Michel M, Chanet V, Dechartres A et al. The spectrum of Evans syndrome in adults: new insight into the disease based on the analysis of 68 cases. Blood 2009;114:3167-72.
18. Wang WC. Evans syndrome in childhood: pathophysiology, clinical course and treatment. J Pediatr Hematol Oncol 1988;10:330-8.

19. Pui Ch, Williams J, Wang W. Evans syndrome in childhood. J Pediatr 1980;97:754-8.

20. Mathew P, Chen C, Wang W. Evans syndrome: results of a national survey. J Pediatr Hematol Oncol 1997;19:433-5.

21. Bader-Meunier B, Aladjidi N, Bellmann F, Monpoux F, Nelken B, Robert A, Armari-Alla C, Picard C, Ledeist F, Munzer M, Yacouben K, Bertrand Y, Pariente A, Chaussé A, Perel Y, Leverger G. Rituximab therapy for childhood Evans syndrome. Haematologica 2007;92:1691-4.

22. Wang W, Herrod H, Pui C, Presbury Q\& Williams J. Immunoregulatory abnormalities in Evans syndrome. Am J Hematol 1983;15:381-90.

23. Karakantza M, Moukaki A, Theodoropoulou M, Bussel B \& Maniatis A. Th1 and Th2 cytokines in patients with Evans' syndrome and profound lymphopenia. Br J Hematol 2000;110:968-70.

24. Notarangelo LD. Primary immunodeficiencies (PIDs) presenting with cytopenias. Hematology Am Soc Hematol Educ Program. 2009;139-43.

25. Seif AE, Manno CS, Sheen $\mathrm{C}$ et al. Identifying autoimmune lymphoproliferative syndrome in children with Evans syndrome: a multi-institutional study. Blood 2010;115:2142-5.

26. Teachey DT, Seif AE, Grupp SA. Advances in the management and understanding of autoimmune lymphoproliferative syndrome (ALPS). Br J Hematol 2010;148:205-16.

27. Sullivan KE, Mullen CA, Blease RM, Winkelstein JA. A multiinstutional survey of the Wiskott-Aldrich syndrome. J Pediatr 1994;125:876-85.

28. Dupuis-Girod S, Medioni J, Haddad E, et al. Autoimmunity in Wiskott-Aldrich syndrome: Risk factors, clinical features, and outcome in a singlecenter cohort of 55 Patients. Pediatrics 2003;111:622-7.

29. Kim JJ, Thrasher AJ, Jones AM, et al. Rituximab for the treatment of autoimmune cytopenias in children with immune deficiency. Br J Haematol 2007;138:94-6.

30. Özsahin H, Cavazzana-Calvo M, Notarangelo LD. Longterm outcome following hematopoietic stem-cell transplantation in Wiskott-Aldrich syndrome: collaborative study of the European Society for Immunodeficiencies and European Group for Blood and Marrow Transplantation. Blood 2008;111:439-45.

31. Lee PP, Chen TX, Jiang LP. et al. Clinical and molecular characteristics of 35 Chinese children with WiskottAldrich syndrome. J Clin Immunol 2009;29:490-500.

32. Ochs HD, Filipovich AH, Veys P et al. Wiskott-Aldrich syndrome: diagnosis, clinical and laboratory manifestations, and treatment. Biol Blood Marrow Transplant 2009;15:84-90.

33. Filipovich AH, Johnson J, Zhang K. WAS related disorders In: Pagon RA, Bird TC, Dolan CR, Stephens K, editors. GeneReviews [Internet]. Seattle (WA): University of Washington, Seattle; 1993-2004 Sep 30 [updated 2007 Apr 27]

34. Shurman SH, Candotti F. Autoimmunity in WiskottAldrich syndrome. Curr Opin Rheumatol 2003;15:446-53. 